University of South Carolina

Scholar Commons

$10-2010$

EMPOWERMENT, INNOVATION, AND SERVICE: LAW SCHOOL PROGRAMS PROVIDE ACCESS TO JUSTICE AND INSTILL A COMMITMENT TO SERVE

Lisa V. Martin

Dale Margolin

Steve Berenson

Karen Pearlman

Maryann Zavez

Follow this and additional works at: https://scholarcommons.sc.edu/law_facpub

Part of the Law Commons 


\title{
EMPOWERMENT, INNOVATION, AND SERVICE: LAW SCHOOL PROGRAMS PROVIDE ACCESS TO JUSTICE AND INSTILL A COMMITMENT TO SERVE
}

\author{
Dale Margolin, Steven Berenson, Lisa Martin, Karen Pearlman Raab, and Maryann Zavez
}

\begin{abstract}
Law schools around the country seek to fill the legal needs of their communities in ways that are both innovative and mutually beneficial to clients and students. This article describes five pro bono and clinical programs, at the University of Richmond School of Law, The Earle Mack School of Law at Drexel University, Catholic University Columbus School of Law, the Thomas Jefferson School of Law, and Vermont Law School, where law students, under the supervision of law professors or community professionals, provide assistance or legal representation to underserved and often marginalized populations needing help with family law problems, including parents accused of abuse and neglect, youth aging out of foster care, homeless families, survivors of domestic violence, homeless veterans with addiction problems, and female prisoners. To develop their programs, the five law schools from the outset collaborated with partners in the community, and they continue to do so as their programs expand and evolve. In addition to helping and empowering clients, these law schools are providing experiential learning opportunities that are transformative for their students. The authors hope that these programs will be instructive for law schools, other academic institutions, the legal community, and community organizations in developing creative collaborations to ensure better access to justice.
\end{abstract}

Keywords: clinic; interdisciplinary; multidisciplinary; family law; innovative; direct representation; holistic; underserved

\section{INTRODUCTION}

Now more than ever, law schools are seeking to serve their communities while simultaneously preparing their students for practice and the job market. At the same time, it may be difficult to integrate these goals without sacrificing one for the other. It would be impossible and perhaps counterproductive to expect that law school clinics and externship programs could fill the enormous gap in legal services around the country. Yet some law schools may be in the unique position, because of private funding, institutional independence, faculty expertise, and student enthusiasm, to both directly impact clients and engender systemic reform.

Underserved and marginalized populations often deal with a variety of family law matters throughout their lives, including problems with custody, visitation, divorce, child support, domestic violence, and foster care, as well as public benefits and housing. Yet in courtrooms across the country they frequently confront these challenges, incident after incident, all alone. Typically, if any legal assistance is available, it is very limited. However, many family law issues are interrelated; limited legal assistance that simply helps a client prepare divorce papers without addressing appropriate parenting arrangements, or potential domestic violence or necessary mental health services, is probably inadequate. In recognition of this, law schools are creating a new wave of experiential learning and service opportunities that provide critical legal assistance to clients, sometimes crossing institutional and disciplinary boundaries.

Five law school programs, diverse in their missions and models, share the common goal of serving clients desperately in need of legal assistance; incorporating the community in their efforts; and providing significant educational, professional, and service opportunities for their students. This article focuses on the creation, implementation, and expansion of experiential learning programs that provide assistance to underserved and marginalized populations at five different institutions in five different

Correspondence: Dmargoli@richmond.edu; sberenson@tjsl.edu; martinl@law.cua.edu; kpearlman@drexel.edu; mzavez@ vermontlaw.edu 
geographical settings: University of Richmond School of Law (Richmond Law), The Earle Mack School of Law at Drexel University (Drexel Law), Catholic University Columbus School of Law (Columbus Law), the Thomas Jefferson School of Law (Thomas Jefferson Law), and Vermont Law School (Vermont Law). The guest editor of this Special Issue of the Family Court Review selected these five programs because of their outstanding commitment to helping underserved populations and because they fill unmet need in their communities by providing legal services to parts of the population whose legal needs often remain unmet - parents with family law problems, especially those accused of abuse or neglect, and children aging out of foster care (Richmond Law); homeless families and immigrant foster children (Drexel Law); victims of domestic violence (Columbus Law); homeless veterans with addiction problems (Thomas Jefferson Law); and female prisoners with family law problems (Vermont Law).

This article, which describes these programs and their creation, collaboration, and funding, is intended to provide guidance to law schools, other educational institutions, the legal community, and community organizations about how innovative collaborations may help, on a local basis, provide access to justice and reduce the "justice gap" for disadvantaged community members. ${ }^{1}$

\section{OVERVIEW OF THE PROGRAMS}

\section{A. RICHMOND LAW'S JEANETTE LIPMAN FAMILY LAW CLINIC}

Richmond Law's Jeanette Lipman Family Law Clinic (FLC) is a live, in-house clinic that provides legal assistance to families and children in the city of Richmond. Law students represent clients under the supervision of the clinic director, an assistant clinical professor of law. Areas of representation include parents accused of abuse and neglect, divorce, custody, domestic violence, children in need of supervision/services (CHINS), public benefits, and housing. FLC also targets youth aging out of foster care by working with the local department of social services to identify and represent this vulnerable and underserved population.

Second and/or third year law students participate for a school year in all aspects of legal representation - in and out-of-court advocacy, client interviews, drafting and filing court documents, and legal writing and research. In order to prepare students, the FLC begins the year with intensive interviewing and courtroom simulation activities.

FLC is a multidisciplinary collaboration with Virginia Commonwealth University (VCU). Graduate students and faculty from VCU's School of Social Work and Department of Psychology help the legal team provide holistic service and referrals to clients.

FLC is located at the new downtown campus of the University of Richmond (UR), convenient to city bus lines and within walking distance of many underserved neighborhoods. The downtown campus is close to the state, county, and federal courthouses and the state capitol. The UR downtown campus houses two other programs: Richmond Law's Pro Bono Center, and an undergraduate program, the Richmond Families Initiative (funded separately from the FLC). FLC students benefit from the community education programs located on site and the assistance of undergraduate student volunteers.

\section{B. DREXEL LAW'S ADOPT-A-SHELTER PROJECT AND ADJUSTMENT OF STATUS FOR UNACCOMPANIED MINORS PROJECT}

Drexel Law opened in 2006 with an ambitious pro bono service graduation requirement. The goal was not only to provide a hands-on educational experience for the students outside the classroom, but also to instill in each student the value that community participation is a duty in the legal profession. With this goal, Drexel Law has created a wide range of pro bono projects and developed relationships with local public interest organizations to ensure that students have direct access to trained attorneys and professionals and that they participate in meeting the needs of underserved communities. Two family law programs at Drexel Law are addressed in this article. 


\section{Adopt-A-Shelter Project}

In 2007, Drexel Law and the Homeless Advocacy Project (HAP) created an Adopt-A-Shelter program to provide direct, community-based outreach to homeless Philadelphians in need of legal services. This project continues today, with a new team of students recruited and trained each year to staff the project. Law students work under the supervision of an experienced HAP attorney to provide a monthly "legal clinic" at the Jane Addams Place, a comprehensive family shelter in West Philadelphia. From the start, the law students are trained by HAP attorneys and work side by side with them through the first weeks of the project, learning aspects of family law and developing sensitivity to working with the homeless population. Beginning with the monthly intake day at the shelter, HAP reviews and opens any case deemed appropriate for representation. Law students assist the attorney on these cases and also conduct research on cases where HAP may not formally be active, but where, nonetheless, some further investigation and/or follow up may occur. In addition to direct representation, the students often develop and conduct community education workshops at the homeless shelter. The Shelter project has several long-term goals: to maintain family unification in the face of pressures that tend to break families apart when they become homeless; to help custodial parents who are homeless or at risk of homelessness to obtain child support; and to develop a meaningful relationship between Drexel Law, the shelter, and the surrounding community in West Philadelphia.

\section{Adjustment of Status for Unaccompanied Minors Project}

In 2008, Drexel Law piloted a program in collaboration with the Hebrew Immigrant Aid Society and Council Migration Service of Philadelphia (HIAS), with the goal of advancing the fair treatment and protection of immigrants and refugees. This project, like the Shelter program, allows for application of the law in an underserved community, develops that application toward a positive social impact that advances a student's grasp of legal structures and institutions, and puts a face on the process - measurable goals that impact lives. Students receive training from HIAS attorneys and work with the attorneys to help abused, neglected, and unaccompanied minor children by providing them with immigration relief and placing them on a path to citizenship. Through this collaboration, HIAS is able to expand its services to immigrant foster children, Drexel Law students get experience not easily found in a classroom, and the broader community is educated on the larger issues associated with this underrepresented group.

\section{COLUMBUS LAW'S FAMILIES AND THE LAW CLINIC}

Columbus Law's Families and the Law Clinic (FALC) is a live in-house clinic in Washington, D.C. (D.C. or District). Three full-time faculty members teach in FALC, which allows FALC to enroll an average of 20 students per semester. FALC's twin goals are: (1) to provide an excellent educational opportunity for students, which develops litigation, advocacy, and other lawyering skills, encourages contemplation of the impact of racism, sexism, and class bias in the context of the legal system, and instills a commitment to social justice and pro bono service; and (2) to combat domestic violence in the community on an individual and a systemic level. To reach these goals, FALC students and faculty provide legal services to individual clients and engage in systemic advocacy through community education projects.

FALC clients are low-income individuals who reside in or have a legal remedy available in the District and who have experienced domestic violence. FALC clients are provided with holistic legal services. The majority of FALC clients begin working with the clinic at one of the two Domestic Violence Intake Centers (DVICs) in the District. Victims of domestic violence obtain an array of services at the DVICs, which are a partnership between the D.C. Superior Court and various community organizations.

FALC students and faculty conduct intake at the DVICs several times each semester. During intake, students interview prospective clients, draft petitions for civil protection orders (CPOs) and represent 
new clients the same day in ex parte hearings for emergency temporary protection orders. The students then prepare for trial and argue the matter at the final hearing 14 days later, unless a settlement has been reached.

By ordering custody and child support, financial assistance, and the physical separation of the parties, CPOs are intended to provide peace of mind and temporary solutions to obstacles that might otherwise prevent a victim of domestic violence from leaving an abusive relationship. Yet CPOs last only one year and therefore do not provide sustainable solutions to many of these problems. FALC attempts to address both the emergency and long-term legal needs of clients by offering representation in divorce, custody, child support, and domestic violence-related immigration matters. This is particularly crucial for clients involved with complicated divorces, interstate custody cases, or seeking immigration remedies such as U visas and Violence Against Women (VAWA) petitions, because they are unlikely to obtain free legal assistance with such matters. FALC students also seek creative solutions to clients' problems outside of the court system by assisting with housing applications and public benefits and engaging in privacy planning.

In addition to representing individual clients, FALC students participate in one of several community projects offered each semester. The aim is to address the root causes of domestic violence and introduce students to non-litigation advocacy methods. The projects vary each semester, in keeping with the community's current needs.

Recently, FALC students have participated in six community projects. They volunteered with the D.C. Bar's Attorney Negotiator Project in D.C. Family Court, assisting parties with drafting consent agreements. FALC students also organized and operated a monthly legal clinic at an emergency domestic violence shelter, where they presented legal information workshops, provided individual advice, and distributed pamphlets and flyers with information about available legal and social services. Students also volunteered at the D.C. Superior Court's Family Court Self-Help Center (SHC) and at a legal clinic at Women Empowered Against Violence (WEAVE), a service provider for survivors of domestic violence. At the SHC and WEAVE, FALC students assisted pro se parties in preparing pleadings and motions, provided information about court processes and relevant laws, and offered resources and referrals. As part of the Teen Dating Violence Prevention Project, FALC students presented a series of workshops on teen dating violence to D.C. high school students, using a curriculum drafted by FALC students and faculty, and organized a train-the-trainer program to prepare high school students to educate their peers about teen dating violence. FALC faculty and students were also engaged in a multi-year campaign to reform the District's laws to increase protections for teen victims of abuse. In response to the enactment of long-awaited reforms, students created fliers and know-your-rights presentations to educate parents, schools, and teens about teens' new rights to protect themselves and drafted proposed administrative court orders, model bench briefs, and court watch questionnaires to help implement and assess the impact of the new provisions.

\section{THOMAS JEFFERSON LAW'S VETERANS LEGAL ASSISTANCE CLINIC}

Thomas Jefferson Law's Veterans Legal Assistance Clinic (VLAC) is an in-house clinic at the Thomas Jefferson School of Law that offers civil legal representation to the residents, alumni, and affiliates of the Veterans Village of San Diego (VVSD) addiction recovery program for homeless veterans. VVSD is a nationally recognized program that provides food, shelter, clothing, substance abuse recovery, mental health counseling, job training, and job placement services to its clients. VVSD organized the first Stand Down, now a national event that brings services to homeless veterans, and it established the country's first "homeless court" in conjunction with the San Diego Superior Court. However, prior to the founding of the VLAC in 2006, VVSD was not able to consistently provide civil legal assistance to its residents and affiliates.

Thomas Jefferson law students enrolled in the VLAC provide legal representation as well as consultations to clients of VVSD on all civil matters. Approximately 80-90\% of the VLAC's caseload consists of family law matters, particularly child support cases. Often, reducing ongoing support payments and/or arrearages to manageable levels is a critical prerequisite to struggling veterans' 
reintegration into productive society. Other family law cases involve custody, visitation, and divorce. Moreover, VLAC assists clients with Food Stamps, SSI and SSDI, Unemployment Insurance, Veterans' Compensation and Pension Benefits, California State Disability Insurance, and San Diego County Medical Services. The VLAC also represents clients on credit and debt matters and postconviction criminal issues, including expunging criminal records, and modifying and terminating probation.

\section{E. VERMONT LAW'S SOUTH ROYALTON LEGAL CLINIC}

Vermont Law's South Royalton Legal Clinic (SRLC), a civil law clinic for low-income clients, established a program in 2006 to assist women inmates with family law issues at the sole women's prison in Vermont, which at that time was located in the same county as the law school. The women's prison project was an outgrowth of family court legal information sessions for pro se litigants that the SRLC and its students had been doing at a local courthouse for more than a decade. In 2009, the women's prison was closed and relocated to a location almost two hours north of the law school. The project has continued at this prison, the Northwest State Correctional Facility (NWSCF), despite the distance, with travel to the prison now occurring on a twice-monthly, rather than weekly, basis.

The distance between the Vermont Law School and the prison has presented challenges, but also an opportunity to rethink delivery of services. Most of the SRLC's work is still done in one-on-one meetings, but future plans include webcam sessions and educational workshops for inmates. By the end of December 2009, the project had assisted more than sixty women, with most of the contacts handled as extended consultations over the course of several visits.

Students enroll in the SRLC for one semester and elect to participate in the women's prison project as part of their caseload. Following a mandatory three-week classroom-based training for all clinic students, those in the prison project accompany the program director to the prison and participate in interviews with the inmates. After the interviews, one student is assigned to each case to do the necessary follow-up work.

\section{CREATION OF THE PROGRAMS}

The creation of these programs was the direct result of assessment of community needs, creative thinking, and hard work by the law schools and their community partners. In each case, the motivating factor for the creation of the specific program was the need in the local community.

\section{A. RICHMOND LAW'S JEANETTE LIPMAN FAMILY LAW CLINIC}

Richmond Law's Jeanette Lipman Family Law Clinic was created as a result of a 2007 "Richmond Families Initiative" (RFI) at the University of Richmond (UR), which initiated a joint venture of Richmond Law and UR's Center for Civic Engagement, an undergraduate service-learning center. The purpose of RFI was to provide pro bono services to Richmond families through law and undergraduate service programs. Richmond Law sought funding from a private foundation for a multi-service interdisciplinary family law clinic that would provide direct legal services to low income children and their families, supplemented by psychological, counseling, and social work services. A crucial aspect of the proposal was that FLC would be located in a new UR downtown campus, in the urban core of the City of Richmond. The plan was for Richmond Law to administer FLC, with subcontracts to VCU's School of Social Work and Department of Psychology.

The need for FLC was acute in the City of Richmond, as none of the local legal aid organizations represent any clients on contested divorce, custody, or domestic violence matters. Furthermore, feedback from community agencies indicated that local social services too often focused on a single 
identified problem rather than on the cluster of issues that may interfere with effective family functioning. The proposed goal of FLC was to provide access to a range of services to support the entire family.

The director of FLC was hired as a full time faculty member and began with four law students and one MSW student in the fall 2008 semester. These students assisted the director with research, community outreach, and creation of policies and procedures in order to launch the clinic. Students devoted 12 hours per week to clinic development, and also participated in the clinic's two-hour seminar, discussing family law topics. In the spring 2009 semester, FLC opened for cases, with eight law students, one MSW student, and three doctoral psychology students enrolled. Students devoted 16 hours per week to case work and participated in a two-hour seminar and a one-hour case rounds session each week. Since the fall of 2009, FLC has been a full-year program for all law, MSW, and $\mathrm{PhD}$ students, which ensures continuity on the cases and in the students' learning.

\section{B. DREXEL LAW'S ADOPT-A-SHELTER PROJECT AND ADJUSTMENT OF STATUS FOR UNACCOMPANIED MINORS PROJECT}

Both of Drexel Law's programs were created as a result of (1) its commitment to exposing students to the broader lessons of a community-based legal education; (2) its commitment to inculcating in its students the duty Drexel Law believes should be shared by all lawyers to make a positive difference in the lives of the legally underrepresented; and (3) its intention to match these commitments to specific community needs.

Accordingly, Drexel Law developed the Adopt-A-Shelter program in response to the growing number of homeless children living in shelters in Philadelphia. In the last decade, the number of homeless families in Philadelphia has continued to increase while the availability of affordable housing, as well as free legal aid and other services to the poor, has decreased. HAP's outreach program is vital to a population who otherwise would not have access to legal services. HAP's collaboration with shelter providers, homeless advocates, community service providers, and the legal community open unique avenues, not only for the homeless to seek help, but also for Drexel Law's students to come in direct contact with these issues and clients in need of assistance. Thus, Drexel Law matched a demonstrated community need with its educational goals for its students.

Similarly, Drexel Law created its collaboration with HIAS, where immigrants, many who are unaccompanied minors, face a host of obstacles (e.g., money, language, general understanding of the American legal system, and lack of community infrastructure) in receiving unfettered and equal access to the law. Moreover, many are subjected to abuse, neglect, and general inattention that contribute to an unequal distribution of legal knowledge and benefits. Again, Drexel Law matched a demonstrated community need with its educational goals for its students, in this case by providing students with access to an immigration-based community service project.

\section{COLUMBUS LAW'S FAMILIES AND THE LAW CLINIC}

Since 1978, the clinical program at Columbus Law has provided services to victims of domestic violence through the creation of the Family Abuse Project. At the time it was created, the Family Abuse Project was a small component within a large general civil practice clinic, and it was one of the only providers of legal services to victims of domestic violence in the District of Columbia. In 1993, Columbus Law received a Title IX grant from the Department of Education to develop FALC as a separate clinic. Two professors applied for the Title IX grant to respond to the increased need for domestic violence related legal services in the District, which had been identified by a communitywide needs assessment, and to more effectively train Family Abuse Project students to assist clients who had experienced abuse. FALC was one of the first law school clinics in the country to focus on providing services to survivors of domestic violence. 


\section{THOMAS JEFFERSON LAW'S VETERANS LEGAL ASSISTANCE CLINIC}

Thomas Jefferson Law's VLAC was created in response to VVSD staff recognition of the need for civil legal assistance for recovering veterans. Veterans who were able to conquer their addictions and obtain gainful employment were nevertheless at risk of having their recovery derailed by the fallout from unaddressed civil legal problems. For example, a veteran with unpaid child support or fees and fines resulting from criminal convictions could have his wages garnished up to $50 \%$ and lose his driver's and other occupational licenses. The resulting loss of a job could lead a veteran back to homelessness and addiction. The VLAC was created to provide the appropriate civil legal assistance necessary to break this tragic cycle.

Recent media attention concerning deplorable conditions at Walter Reed Army Medical Center and the struggles of veterans returning from Afghanistan and Iraq has highlighted the need for legal assistance among veterans. Indeed, numerous bar association and pro bono programs now help veterans obtain disability and medical benefits from the U.S. Department of Veterans Affairs. ${ }^{2}$ However, the veterans at VVSD themselves, as well as their advocates, identified family law as the primary area in which they could benefit from legal representation. In response to this need, Thomas Jefferson Law created the VLAC, one of the first programs in the country to provide comprehensive family law legal services to veterans.

\section{E. VERMONT LAW'S SOUTH ROYALTON LEGAL CLINIC}

For Vermont Law, the creation of the SRLC's program to assist women prisoners with family law problems began in 2006, when SLRC representatives and administrators at the local women's prison assessed the need for an on-site family law outreach program. Not surprisingly, a significant number of inmates were finding themselves enmeshed in family court proceedings during their incarceration, invariably involving their children. When children resided in the custody of relatives, inmates were often forced to petition the court for meaningful visitation; other children wound up in foster care, which entailed months or years of meetings, reviews and court hearings. According to prison administrators, inmates also needed assistance responding to divorce petitions and with reducing child support obligations so that they did not face unrealistic child support arrearages upon release.

The local legal landscape helped define the parameters of the prison project. In child welfare cases, mothers would have court-appointed public defenders, so the SRLC decided to have students assist the public defenders in a secondary role, conducting research, attending case plan reviews, facilitating contact between inmates and the myriad professionals involved in these cases, and helping the inmates advocate for services under case plans. The SRLC's advocacy is necessary because despite federal and state law mandating reunification efforts, child welfare agencies often do little to facilitate parent-child contact or other case plan goals when mothers are incarcerated. In the non-child welfare family court matters, the SRLC determined to provide assistance by helping inmates navigate pending legal proceedings, typically by explaining the relevant statutes and/or assisting with motions or other court filings.

\section{COLLABORATION AND COMMUNITY INVOLVEMENT}

For each of these programs, collaboration with community partner(s) was the essential link and the catalyst that enabled the creation of the program.

\section{A. RICHMOND LAW'S JEANETTE LIPMAN FAMILY LAW CLINIC}

Richmond Law recognizes that the key to the success of FLC is the collaboration between the law school (a private institution) and VCU, a public university of more than 32,000 students located in the 
heart of downtown Richmond. Importantly, this was the first clinical partnership between these two institutions; their goal was to serve the community conveniently and holistically.

VCU's School of Social Work places up to four second-year MSW student interns with FLC each year. The social work students actively participate in all aspects of the clinic's cases as part of the legal "team." This includes assisting with interviews, conducting out-of-court advocacy and consultation with service providers, and researching and providing referrals to community agencies. The MSW students and faculty do not provide any separate counseling and do not maintain a confidential social work relationship with any FLC clients or anyone involved with the cases. In addition, the MSW students attend all clinic seminar classes and contribute enormously to the breadth of the discussion.

VCU's Department of Psychology places up to four first-and second-year doctoral candidates with FLC each year. The doctoral students, as part of the legal team, have helped with case consultation and assessment as well as service planning. This includes attending clinic class sessions on a weekly basis, consulting with law and social work students on individual cases, assessing and interpreting mental health records of clinic clients, assessing the mental health needs of clients when appropriate, and conducting psychological evaluations of clients on request.

Multidisciplinary collaboration is not without its challenges. Differing ethical rules between the law and social work disciplines have created lively seminar discussions and informed tense but critical decision-making on cases. For example, according to the Code of Ethics of the National Association of Social Workers, social workers must be "cognizant of their dual responsibility to clients' interests and the broader society's interest in a socially responsibly manner."3 This perspective sometimes conflicts with the legal profession's ethical obligation to conduct client-directed advocacy, particularly when multidisciplinary teams create service plans. FLC social work students and faculty frequently inquire about a client's personal issues, which may be detrimental to a client if they come to light in court or to the attention of adversaries. While these issues must be addressed in order to provide holistic services, FLC lawyers must also manage client liabilities.

FLC also has had to manage differing obligations across disciplines concerning the duty to report child abuse or neglect. In Virginia, lawyers are not mandatory reporters, and there is no case law or attorney general opinion on collaboration, but with the advice of the state bar's ethics panel, FLC developed a written protocol for all students and faculty. According to the protocol, any time a social work or psychology student identifies a potential obligation to report, FLC's director and the student's faculty supervisor assess the severity of the situation, which can include further investigation with the client's consent. The client must be counseled on each step, and ultimately must consent to a report, unless FLC has strong evidence that imminent bodily harm is about to occur to a child. So far no mandatory reporting situations have arisen, but FLC is aware that the protocol may have to be revised in practice.

Despite the challenges, FLC's multidisciplinary collaboration is a positive experience for the faculty and students, and this collaboration has been bolstered by support from the two local courts. The judges and staff at both courts have been extremely supportive of the program. This support has included help in planning and creating strategies for obtaining cases, including allowing FLC faculty and students to attend preliminary protective order hearings and offer their legal services to pro se litigants; arranging for referrals in CHINS cases, through which FLC provides pre-adjudication, preventive legal services; permitting FLC students (law, MSW, and PhD) to observe court hearings; and encouraging FLC law students to litigate and enter appearances in divorce and appeals cases.

\section{B. DREXEL LAW'S ADOPT-A-SHELTER PROJECT AND ADJUSTMENT OF STATUS FOR UNACCOMPANIED MINOR'S PROJECT}

In both Drexel Law projects, collaboration with the public interest organizations (HAP and HIAS) not only provides access to clients, but also (1) cements a working relationship with an organization that fits well with Drexel Law's vision for its students; (2) trains Drexel Law's students under the supervision of qualified professionals; and (3) implements law student knowledge and skills at the organization. Drexel Law has found that cross-disciplinary cooperation can involve organizations with diverse missions and at a variety of levels, provided the principles that further community aid and train its 
students are constant. With the Adopt-A-Shelter project, students train under HAP staff and attorneys. This commitment to the strength of the collaboration ensures that the client receives a high level of service and also that the assistance provided is an expansion of a pre-existing infrastructure and does not simply create undue work for the organization. At HIAS, legal representation of unaccompanied immigrant minors entails cross-system advocacy involving, among others, the child welfare system, law enforcement, and the immigration system, as well as the students. HIAS provides training to the law students, guides them through these various networks, and gives them on-site legal supervision.

The key to Drexel Law's collaborations is getting to know community leaders, learning what the community needs, matching community needs to specific project goals, and demonstrating the potential mutual benefits of the relationship. By engaging local leaders, Drexel Law's pro bono program has provided more than 25 student volunteers who have served over 60 clients through these two projects in the past two years.

\section{COLUMBUS LAW'S FAMILIES AND THE LAW CLINIC}

Columbus Law understands that FALC would not succeed without the support and cooperation of its community partners, including the D.C. Superior Court, the D.C. Bar, My Sister's Place, WEAVE, the SHC, and the high schools involved in the teen dating violence project. FALC's community projects typically arise from the involvement of FALC faculty members in local coalitions of domestic violence advocates and legal services providers and in committees of the D.C. Bar. Some projects, such as staffing the SHC and the WEAVE legal clinics, involve FALC supporting long-standing, well-established resources for the community. Other projects, such as serving as attorney-negotiators and developing community education materials regarding new District laws, result from community partners asking FALC to spearhead or participate in new efforts. A third group of projects, such as the clinics run by FALC at the emergency shelter, develop from the identification of an unmet need in the community by FALC faculty, which FALC faculty and students work to address in partnership with other local service providers. Across all of the community projects, FALC faculty and students solicit feedback from community members and partner organizations to assess the effectiveness of its efforts and ensure that FALC's efforts continue to respond to community needs.

\section{THOMAS JEFFERSON LAW'S VETERANS LEGAL ASSISTANCE CLINIC}

Thomas Jefferson Law views VVSD as an equal partner in VLAC. Prospective clients are screened for referral to VLAC by VVSD according to the individual's progress in the rehabilitation program. Once a client is accepted for representation, VLAC students work closely with the other VVSD professionals on the case, particularly the case manager, who is a California certified alcohol and drug treatment counselor. Additionally, VVSD residents engage in mental health counseling with social work students and their supervisors from other California universities. ${ }^{4}$ This multidisciplinary team ensures that all aspects of the client's rehabilitation program are complimentary, maximizing the chances for successful recovery.

For years, VVSD and the San Diego Superior Court have worked together on San Diego's annual Stand Down, and in 2009, the court agreed to hear child support cases as part of the event. The cooperation of the San Diego Department of Child Support Services (SDDCSS) was also instrumental to this development. VLAC provided legal representation to all child support obligors appearing at this special court session. This collaboration expanded the impact that all four institutions-VVSD, VLAC, SDDCSS, and the San Diego Superior Court - can have on the lives of recovering veterans.

There was some initial hesitancy on the part of some of VLAC's collaborators to have law students provide legal assistance. VVSD and its residents, however, preferred a student attorney to no legal assistance, ${ }^{5}$ and it appears that the students have won over the initial skeptics through hard work, preparation, and professionalism.

From the students' perspective, VLAC has provided a unique opportunity to get "hands-on" legal practice experience in absolutely "real world" settings, and has thus been extremely popular given the 
pragmatic orientation of many of today's law students. The opportunity to assist those who have served our country, but who are presently struggling, has been an additional reward from the students' perspective. From an academic standpoint, the goal of the program has been to get students to the point where they will be able to handle routine family law matters confidently and on their own as soon as they complete law school.

\section{E. VERMONT LAW'S SOUTH ROYALTON LEGAL CLINIC}

Administrators at both prisons have been key collaborators with Vermont Law's women's prison project. Further, Vermont's Director of Women and Family Services was supportive of the initial concept because she recognized that many women faced family court matters during their incarcerations. The Director has helped to ensure the program's ongoing success, in particular, by coordinating communication between the SRLC and Corrections administrators, prison officials, and inmates. Developing the project from the beginning with input from all levels of prison administration was crucial to the staff's acceptance and promotion of the program.

Currently the prison project partners with Vermont Children's Aid (VCA), so that all referrals come through the VCA social worker, whose role at the prison is to coordinate and oversee visits between the mothers and their children. One of VCA and the SRLC's joint goals is to establish an administrative mechanism to identify an inmate's family court legal needs as soon as possible after she enters the prison and make referrals to the SRLC's women's prison project as appropriate.

By its nature, the prison project involves collaboration with attorneys-of-record and state agencies. When an issue is outside the scope of the project-for example, if a woman claims she has been discriminated against due to race or disability, or there is an internal grievance - the Clinic works with the state's prisoners' rights office and the Vermont Human Rights Commission to ensure that her claim(s) reaches the proper channel.

\section{INSTITUTIONAL SUPPORT AND OUTSIDE FUNDING}

Funding for each of these programs is different, and reflects the unique opportunities and support available.

\section{A. RICHMOND LAW'S JEANETTE LIPMAN FAMILY LAW CLINIC}

FLC is funded by a grant from a private philanthropist, Jeanette Lipman, whose foundation makes grants to a variety of programs in the community. ${ }^{6}$ FLC is housed in a historic bank building, the lease of which was donated by a UR trustee who owned the property. The trustee also renovated the space at no cost to UR. The renovation was done in order to match FLC's needs (and that of the other two downtown programs).

UR and Richmond Law also have provided important support for FLC. UR's President and Provost have both visited the FLC numerous times and conducted University-wide meetings about how to bolster FLC's mission. UR also secured the downtown location, provided extra funding and staff to complete the renovation, and sponsored a substantial and well-publicized launch event for the downtown campus. Richmond Law has also supported FLC by integrating it into the curriculum and the culture of the school, publicizing the program, and encouraging Richmond Law professors to hold events in the downtown space and discuss FLC in their classes. Public relations efforts have resulted in excellent publicity for the program.

\section{B. DREXEL LAW'S ADOPT-A-SHELTER PROJECT AND ADJUSTMENT OF STATUS FOR UNACCOMPANIED MINORS PROJECT}

Drexel Law's commitment to its Pro Bono Program, including the Adopt-A-Shelter Project and the Unaccompanied Minors Project, is a core component of Drexel Law's curriculum. Drexel Law 
students perform a minimum of fifty hours of school-approved pro bono service. The Director for Public Interest Programs coordinates projects and matches students with outside opportunities.

Along with providing a director to run the program, Drexel Law prominently advertises the Pro Bono Program and provides for recognition of service throughout the year and with awards at graduation. Community events also bring together the students around the Program not only to encourage conversation and build awareness, but also to demonstrate the institutional nature of the Program.

In funding its Pro Bono Program, Drexel Law benefits from a consistent network of institutional and community support. In Pennsylvania, IOLTA money (Interest on Lawyers Trust Accounts) is available to fund public interest initiatives. Drexel Law has chosen to devote a significant portion of its IOLTA money to fund a number of its collaborative pro bono projects with leading legal services providers in the Philadelphia community. The funding allows the law school to provide grants to organizations, which allows the organization to free up a percentage of the attorneys' time to train and supervise students. Drexel Law also devotes annual funding to the program, consistent with its placement as a graduation requirement. Additionally, Drexel Law has created a grant program for students who want to continue working with its partner public interest organizations and take unpaid public interest internships. Students also participate in annual fundraisers ensuring that they understand the financial obligations that come with the provision of free legal services in the community. To the extent possible, Drexel Law matches student money raised, further showing its support for pro bono work.

\section{COLUMBUS LAW'S FAMILIES AND THE LAW CLINIC}

Columbus Law provides support for FALC, in particular by staffing FALC with three full time faculty members and, most recently, by allocating additional space in the law school building for clinic student workrooms. The dean of Columbus Law and other members of the law school administration regularly include stories about FALC in presentations to new students, alumni, the Board of Visitors, and other audiences; provide information about FALC in printed publications such as admissions brochures and alumni newsletters; and feature clinic victories on the law school website.

Columbus Law's clinical program was established in 1969 with funding from the Council on Legal Education for Professional Responsibility (CLEPR), and as noted, FALC's funding originally derived from a Department of Education Title IX grant. Today FALC is primarily funded by the Law School, and it also receives support from the D.C. Bar Foundation and alumni contributions.

\section{THOMAS JEFFERSON LAW'S VETERANS LEGAL ASSISTANCE CLINIC}

VLAC was launched by an anonymous private donation. In addition, the donor's support makes possible the hiring of a fellow for the VLAC each year. The fellow helps supervise students, manage the VLAC office, and provide direct representation to VLAC's clients.

Thomas Jefferson Law supports VLAC through the appointment of a tenured member of the law school faculty to direct the program. Furthermore, ongoing funding for the program is drawn from the law school's budget.

In 2009, VLAC was the recipient of $\$ 50,000$ in cy pres funds from an antitrust class action settlement against the smokeless tobacco industry. VLAC is presently pursuing a variety of grant proposals in an effort to expand the scope of the services it is able to offer.

\section{E. VERMONT LAW'S SOUTH ROYALTON LEGAL CLINIC}

Approximately a year ago, the SRLC secured a federal grant that has helped defray salary and other expenses of the prison project. Before then, Vermont Law funded the prison project entirely out of the law school's budget. Vermont Law is also supportive of the project - the program director is a tenured professor at Vermont Law who spends approximately $10-15 \%$ of her time in the SRLC on the prison caseload. 


\section{CONCLUSION}

Throughout the country, law schools try to meet the legal needs of the underserved, needs that are exacerbated by our struggling economy. Creating clinical and pro bono opportunities for law students provides important training and benefits for the students, as well as the clients who are assisted. The law school programs described in this article are filling family law needs that are not being met elsewhere, and they are doing so in innovative ways, working closely and collaboratively with other institutions and community providers.

None of these five programs would exist without the support from, and integration of, the community and community-based organizations. As demonstrated throughout this article, collaboration was the key to fostering a strong working relationship and a willingness on the part of the organizations to devote their time and resources to working with the students. Before initiating projects, the schools interacted with community partners to assess the need for, and the structure of, the projects. These law school programs continue to involve the community by evolving their programs to the needs of their collaborating partners, and most importantly, of the clients they strive to empower and serve.

\section{NOTES}

1. The "justice gap" is identified in Robert Echols, State Legal Needs Studies Point to “Justice Gap," Dialogue 32 (Summer 2005), available at http://www.nlada.org/DMS/Documents/1125689452.32/Dialogue.pdf) and LEGAL SERVICES CORP., DOCU-

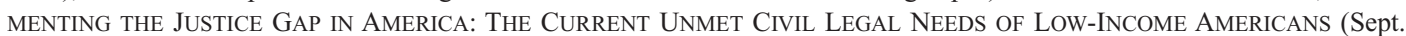
2009), available at $\mathrm{http} / /$ www.lsc.gov/pdfs/documenting_the_justice_gap_in_america_2009.pdf.

2. See, e.g., the National Veterans Legal Services Program (NVLSP) Lawyers Serving Warriors project available at www.lawyersservingwarriors.com. Firms such as Wilmer Cutler, Morrison and Foerster, and DLA Piper have all launched initiatives to bring pro bono legal representation to needy veterans. See, e.g., Lynne Marek, Law Firms Massing to Help War Vets: A 'Staggering' Need for Representation, NAT'L L.J., Sept. 26, 2007, at 1.

3. http://www.naswdc.org/pubs/code/default.asp.

4. San Diego State University and University of California San Diego.

5. Thomas Jefferson Law believed that because it and the other two San Diego law schools, San Diego State University and the University of California at San Diego, do not have extensive in-house clinical offerings, the other partners, including the courts and government agencies such as SDDCSS, were initially hesitant to deal with VLAC student attorneys as bona fide legal representatives, despite their certification under the California Bar's Practical Training for Law Students (PTLS) program.

6. The relationship between UR and VCU is governed by two distinct Memorandums of Understanding, which include yearly payment to each department out of the FLC's grant-funded budget.

Dale S. Margolin is a clinical professor and the director of the Jeanette Lipman Family Law Clinic at the University of Richmond School of Law, which represents low-income families in the city of Richmond. A recognized leader in family law and foster care issues, most recently she was awarded the FACES of Virginia Empowerment Award. Her scholarship focuses on youth aging-out of foster care as well as the constitutional rights of parents in child protective proceedings, particularly mentally disabled parents. Before becoming a professor, she was a Skadden Fellow at the Legal Aid Society in New York and a Clinical Teaching Fellow at St. John's School of Law. She graduated with honors from Stanford University and received her J.D. from Columbia Law, where she was a Harlan Fiske Stone Scholar.

Steven K. Berenson has been a law teacher for fourteen years, first as a fellow at Harvard Law School, then at Nova Southeastern University, and presently at Thomas Jefferson School of Law. In addition to directing the Veterans Legal Assistance Clinic, he teaches and writes in the areas of Professional Responsibility and Family Law. Prior to teaching, he worked as an Assistant Massachusetts Attorney General, focusing in the areas of consumer protection law and civil litigation. He is a member of the state bars of California, Florida, and Massachusetts and is licensed to practice before numerous federal courts and administrative agencies.

Lisa Martin co-teaches the Families and the Law Clinic at Columbus School of Law, Catholic University of America, where she supervises law students representing victims of domestic violence in emergency protection order, family, and immigration matters and undertaking community education projects. Before coming to Catholic University, she was a staff attorney and program manager at Women Empowered Against Violence, where she provided holistic services to teen 
survivors of dating violence with a team of lawyers, social workers, and advocates. She has published in the areas of family, domestic violence, and international human rights law. She is a graduate of the Georgetown University Law School and the College of William and Mary.

Karen Pearlman Raab is the director for Public Interest and Pro Bono Programs at The Earle Mack School of Law at Drexel University. She created and is directly responsible for Drexel Law's pro bono requirement and oversees all other public interest programs at the law school. She has been instrumental in fostering a culture at Drexel that values and rewards public service. She currently serves on the Equal Justice Conference Planning Committee and is a published author and frequent lecturer in her field. Active within the community, she serves on the boards of the Homeless Advocacy Project and the Young Friends of the University of Pennsylvania Museum. She has been the co-chair of the Historical Society of Pennsylvania's Founder's Award since 2008.

Maryann Zavez is a professor of law at Vermont Law School whose primary teaching role is clinical supervision of student learning in the South Royalton Legal Clinic, a civil legal aid clinic, on the Vermont Law School campus. She also teaches a family law course in the law school's General Practice Program. 